\title{
Evaluation of effects of various drugs on platelet functions using phorbol I 2-myristate I3-acetate-induced megakaryocytic human erythroid leukemia cells [Corrigendum]
}

Tada T, Aki K, Oboshi W, Kawazoe K, Yasui T, Hosoi E. Drug Des Devel Ther. 2016;10:3099-3107.

In page 3103 , there is an error in Figure 3B:

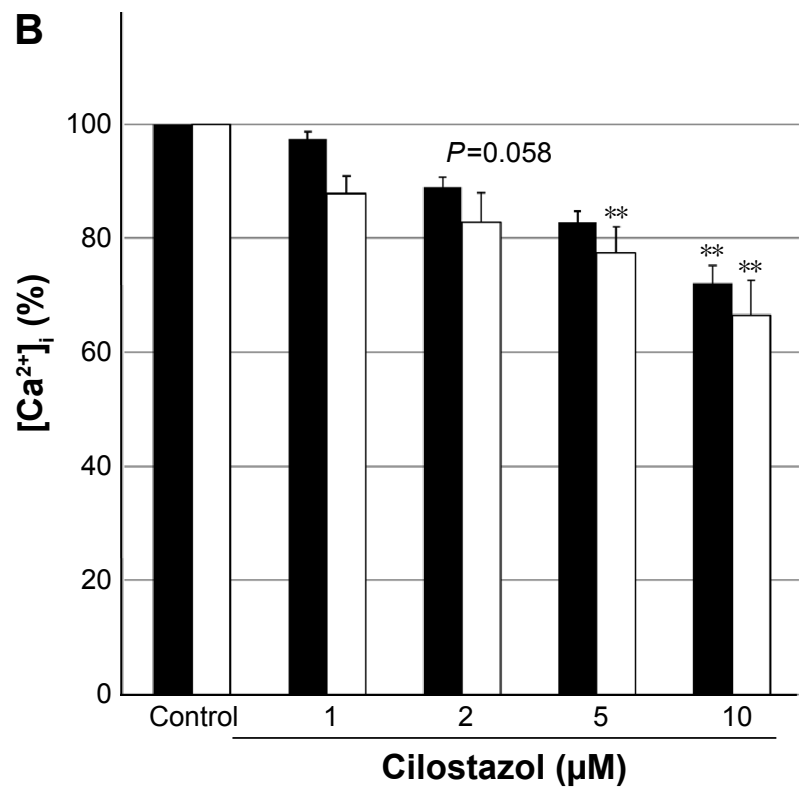

The correct figure is as follows:

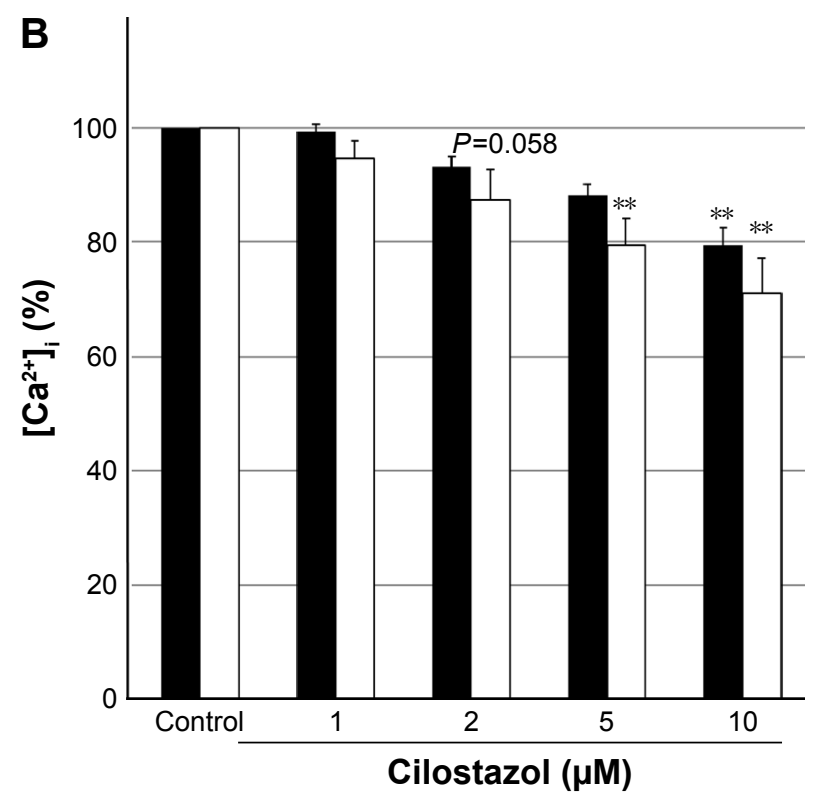

Notes: $\mathbf{\square}$, untreated HEL cells; $\square$, PMA-induced HEL cells.

Any reference to this figure in the main text of the paper is still correct as is.

\section{Publish your work in this journal}

Drug Design, Development and Therapy is an international, peerreviewed open-access journal that spans the spectrum of drug design and development through to clinical applications. Clinical outcomes, patient safety, and programs for the development and effective, safe, and sustained use of medicines are the features of the journal, which
CORRIGENDUM 